\title{
Calvin: A Prophet without a Prophecy
}

\author{
Max ENGAMMARE
}

Only a few months after Calvin's death, August 1564 to be precise, Theodore Beza composed a preface for the posthumous French edition of Calvin's commentary on the book of Joshua: it took the form of a brief biography of the reformer. ${ }^{1}$ Describing the death of Calvin, Beza recalled the sadness that invaded Geneva on the announcement of the death of the prophet of God: "The following night, and the day after as well, there was much weeping in the city. For the body of the city mourned the prophet of the Lord, the poor flock of the Church wept the departure of its faithful shepherd, the school lamented the loss of its true doctor and master, and all in general wept for their true father and consoler, after God."2

Beza did not clarify the meaning he gave here to the word "prophet," but he did associate it with the body of the city. By the pre-eminent place given to the expression in the list-body of the city, church, school, the population of Geneva as a whole-and since there are many references at this period to the body of the Small Council or the body of the General Council, I take this body to mean the city in the classical sense of the state, Calvin having thus been the prophet of the political and juridical state of Geneva.

However, in another text written the following year, prefacing another posthumous publication of Calvin's, the edition of his lectures on the first twenty chapters of Ezekiel, ${ }^{3}$ Beza was more precise in the

I thank very much Francis Higman, who translated kindly and so precisely this paper.

1. Rodolphe Peter and Jean-François Gilmont, Bibliotheca Calviniana: Les CEuvres de Jean Calvin publiées au XVIe siècle, vol. 1, bk. 2, Écrits théologiques, littéraires et juridiques, 1555-1564, Travaux d'Humanisme et Renaissance 281 (Geneva: Droz, 1994), 1053-55, 1070-73 (no. 64/4; Latin ed. no. 64/9).

2. Calvini opera (abbreviated hereafter as $C O$ ) 21 , cols. 45-46. This passage is frequently quoted in the secondary literature, most recently by Bernard Cottret, Jean Calvin: Biographie (Paris: Jean-Claude Lattès, 1995), 267.

3. "Leçons de M. Jean Calvin sur les vingt premiers chapitres du Prophète Ezechiel" (1565), fol. *2-*5, in Correspondance de Théodore de Bèze, ed. Hippolyte Aubert et al., Travaux d'Humanisme et Renaissance 103 (Geneva: François Perrin, 1970), 6: 15-25 (no. 373). I am most grateful to Alain Dufour for having drawn my attention to this text.

Max Engammare is director of Librairie Droz S.A. and associated researcher at the Institut d'Histoire de la Réformation, both in Geneva. 
meaning he gave to the word "prophet," when he wrote of the prophetic spirit that inspired Calvin.

Four years after the Colloquy of Poissy, France had been devastated by the first War of Religion, and Beza recalled that Calvin, in dedicating his Lessons on Daniel to the French Churches (in 1561), had foreseen the coming struggle: "I warn you that you will have to suffer conflicts much more violent than you imagine; but however much the fury of the wicked overflows, and even if they unleash all hell, remember that the conflict is willed on you by the sovereign heavenly Master." 4

Since calamities followed these predictions, while at the time agreement seemed within sight, Beza deduced that Calvin "announced this by a prophetic spirit." 5 Beza clarified immediately that this prediction did not come from "that false and profane judicial astrology" against which, as is known, Calvin had written a short treatise (1549). ${ }^{6}$ But since Calvin was expounding a prophetic book, and since he saw the same ills flourishing in France as had previously darkened the life of the chosen people, Beza justified the prediction: "Why would he not have stated that the same punishments hung over the heads of those who did not repent? By the same token Luther foresaw and foretold the sufferings that were about to fall on all Germany because of the contempt of the Word of God." 7

These two exceptional men, ${ }^{8}$ Luther and Calvin, thus announced the most terrible ills in store for those who turned away from God, in this way embodying anew the verve of the Old Testament prophets. On the authority of Theodore Beza, therefore, it is not illegitimate to write of Calvin as a prophet.

To call Calvin a prophet may nonetheless give rise to two types of distrust. On the one hand it may revive the ultraliberal, sometimes positivist criticism that considered Geneva in the second half of the sixteenth century a theocracy in which Calvin governed as high priest, a real ecclesiastical dictator. On the other hand, it may make Calvin into a prophet foretelling apocalyptic visions of the end of time-this prophetic figure enjoying a renewed interest in this end of the second millennium. Since Calvin insisted regularly that the time of prophecy was ended by Jesus Christ, ${ }^{9}$ I shall therefore ignore these two extreme

4. Beza, "Leçons," in Correspondance de Bèze, 6:20.

5. Beza, "Leçons," in Correspondance de Bèze, 6:20.

6. Advertissement contre l'astrologie judiciaire, ed. Olivier Millet, Textes littéraires français 329 (Geneva: Librairie Droz, 1985).

7. The preface to Beza, "Leçons," in Correspondance de Bèze, 6:20.

8. Beza regularly associated them, for example in the dedication to Renée de France, in Beza, "Leçons," in Correspondance de Bèze, 7:100 (no. 468).

9. Institutio religionis christianae 2.15 .2 (an addition in 1559-1560); see also a passage in sermon 86 on Genesis (Gen. 18:16-21), dated 18 April 1560: "prophecies ended at the 
tendencies, despite a remark by Theodore Beza to which I shall return in my conclusion. While labeling Calvin a prophet, therefore, I reaffirm that he never prophesied-whence the paradoxical title of this article. On the other hand, I shall try to define the senses in which he was a prophet in his own eyes and in those of his contemporaries, according to three axes: as commentator of Scripture; as advisor or guide of the political powers; and as a man convinced that he had received from God a special vocation.

\section{Calvin and the Old Testament Prophets}

Many studies, favorable or unfavorable ${ }^{10}$ have long associated the image of Calvin with that of the Old Testament prophets. Several recent studies have developed the argument by defining more precisely the prophetic status of John Calvin, especially those studies that have been concerned with his sermons. ${ }^{11}$ A review will enable us to stake out the different senses given to the adjective "prophetic."

In his Jeune Calvin, Alexandre Ganoczy emphasized the prophetic awareness at the heart of his pastoral and reforming vocation.12 Returning, twenty years later, to his argument in a famous article, "Calvin avait-il conscience de réformer l'Église?"13 Ganoczy confirmed his position. Calvin chose the prophetic path, aware of his extraordinary vocation (munus extraordinarium) and "legitimizing his work as a reformer by an appeal to the model of Old Testament prophets." 14

The same ideas appear in Richard Stauffer. Based on Calvin's use of first-person discourse in his sermons, Stauffer also defended the prophetic consciousness of Calvin, although rather too rapidly and with insufficient argument, ${ }^{15}$ and with a marked hagiographical tendency, especially when he claimed that Calvin never used the pulpit

coming of our Lord Jesus Christ" (MS Bodleian, Oxford, fol. $574 \mathrm{v}$ ); or again, the passage from the commentary on Romans quoted below (note 55 ).

10. In Calumniae nebulonis cuiusdam, quibus odio et invidia gravare conatus est doctrinam Johannis Calvini de occulta Dei providentia: Johannis Calvini ad easdem responsio, the third calumny begins, "Contra tertium de differentia voluntatis et permissionis hoc dicunt: Calvinus dicit se esse prophetam Dei et nos dicimus Calvinum esse prophetam diaboli" (cf. CO 9, col. 276). In his reply Calvin did not refute the statement that he was a prophet!

11. It is interesting to note that Fritz Büsser, in his study Calvins Urteil über sich selbst (Zurich: Zwingli-Verlag, 1950), does not mention the equation Calvin-prophet.

12. Alexandre Ganoczy, Le Jeune Calvin: Genèse et évolution de sa vocation réformatrice, Veröffentlichungen des Instituts für europäische Geschichte Mainz 40 (Stuttgart: Steiner, 1966), 336-68; position defended in his general conclusion, $362 \mathrm{f}$.

13. Revue de Théologie et de Philosophie 118 (1986): 161-77, especially 172-77.

14. Ganoczy, "Conscience de réformer," 176.

15. Richard Stauffer, "Les, Discours à la première personne dans les sermons de Calvin," in Interprètes de la Bible: Etudes sur les Reformateurs du XVIe siècle, Théologie historique 57 
for the expression of his own ideas, ${ }^{16}$ or that the Reformer always wanted to be a listener to his own sermons, God's pupil along with all the other members of the congregation. This is not of course false, but the analysis is short-circuited by these uncritical remarks.

In his study of Calvin's rhetoric, Olivier Millet regularly encountered the image of the prophet. ${ }^{17}$ Calvin was attracted and seduced by prophetic rhetoric: it was prophetic fervor that legitimized and structured Calvin's fervor; it was the prophetic model that above all provided the model for Calvin's preaching. Millet too adopted Ganoczy's analysis, in evoking the prophetic concept of Calvin's reforming mission. ${ }^{18}$ Basing himself on the title page of the 1544 edition of the Excuse aux Nicodemites and its quotation from the prophet Amos, ${ }^{19}$ which Calvin applied to himself- "They hate him that rebuketh in the gate, and they abhor him that speaketh uprightly"-Millet gives a subtle analysis of the Reformer's discourse: "There is thus on Calvin's part the implicit claim to have a prophetic role (appropriation of the source text and of its general context), according to the modalities at the same time emotional and ironic which characterize literarily the discourse of Amos, and moreover an indication of his purely human and rational quality as advisor ('at the gate'), as interpreter of public morality." 20 The analysis is subtle in that it underlines the ambiguous character of Calvin's prophetic awareness: sometimes Calvin considered his vocation as being based on an extraordinary prophetic ministry, sometimes simply as a pastoral and teaching ministry. Other writers-I have in mind Rodolphe Peter-have emphasized the importance of the image of one particular prophet in Calvin's life and work, namely the prophet Jeremiah. ${ }^{21}$

Finally, to conclude this brief survey of recent stimulating studies, Bernard Cottret, in his biography of Calvin, ends the chapter on the

(Paris: Beauchesne, 1980), 183-223, especially 185-93. Originally published in Revue d'histoire et de philosophie religieuse 45 (1965): 46-78.

16. Stauffer, "Discours à la première personne," 187.

17. Olivier Millet, Calvin et la dynamique de la parole: Étude de rhétorique réformée, Bibliothèque littéraire de la Renaissance, 3d ser., 28 (Paris: Champion, 1992), especially 268-79, 324-29.

18. Millet, La Dynamique de la parole, 135, 315.

19. Millet, La Dynamique de la parole, 447-49. The quotation from Amos 5:10 is, "Odio habuerunt corripientem in porta, et loquentem recta abominati sunt."

20. Millet, La Dynamique de la parole, 449.

21. Several works by Peter could be cited, including his edition of the sermons on Jeremiah (Sermons sur les livres de Jérémie et des Lamentations, ed. Rodolphe Peter, Supplementa Calviniana 6 [Neukirchen: Neukirchener Verlag, 1971], xiv-xvi). Peter quotes a remark of Calvin's in 1552: "If it is claimed that I am not the prophet Jeremiah, that is true. But nonetheless I bear the same word which he announced, and I can protest before God that I serve him faithfully, according to the measure of his Spirit which he has given me" (xiv). 
last years of the Reformer's life and his death with these cautious words: "Agreed, Calvin was not a saint. Perhaps he was a prophet." 22 It is this "perhaps" that I would like to transform into "certainly": "certainly he was a prophet." In order to do so, I wish to look more closely at Calvin's prophetic awareness.

\section{CAlvin, EXPOUNDER OF THE Bible}

Calvin affirmed himself as a prophet firstly as expounder of the Bible. Already in his first biblical commentary, on the Epistle to the Romans, in 1539, one verse gave Calvin the opportunity to explain what he understood by prophecy. In chapter 12, Paul stated that all the members of the church had different gifts, and he listed them, associating each with the aim towards which each gift tended: "Having then gifts differing according to the grace that is given to us, whether prophecy, let us prophesy according to the proportion of faith [analogia fidei]; or ministry, let us wait on our ministering: or he that teacheth, on teaching; or he that exhorteth, on exhortation: he that giveth, let him do it with simplicity; he that ruleth, with diligence; he that sheweth mercy, with cheerfulness" (Rom. 12:6-8).

In his commentary, Calvin recognized that the first segment, "prophecy according to the proportion or analogy of faith," was the most difficult to explain. He began by setting aside the interpretation of those who "take prophecy to mean that gift of divination which was seen to grow up and flourish in the Church at the time of the beginnings of the Gospel"; 23 he then offered his own reading: "Thus today in the Christian Church, since Christ and his Gospel have put an end to all the former prophecies and to all the oracles of God, prophecy is almost nothing other than a correct understanding of the Scripture and a singular skill in explaining it well." 24

In his commentary on Paul's first Epistle to the Corinthians, Calvin confirmed this interpretation for the prophets of the New Covenant: "By prophets he [Paul] means, in my judgment (meo quidem judicio),

22. Cottret, Jean Calvin, 268.

23. Johannis Calvini Commentarius in epistolam Pauli ad Romanos, ed. T. H. L. Parker, Studies in the History of the Christian Church 22 (Leiden: Brill, 1981), 270; Commentaires de M. Jehan Calvin sur toutes les Epistres de l'A postre S. Paul . . Item sur les Epistres Canoniques (Geneva: Conrad Badius, 1556), 1: 135.

24. Commentarius in epistolam Pauli and Commentaires sur toutes les Épistres. Calvin also defined, a little later, what he understood by "the rule of faith": "By the word 'faith, [Paul] understands the first bases and principal maxims of religion, with which all doctrine which is found not to be in accord will by this means be denounced and declared false" (271 [Latin]; 1: 135 [French]). The analogy of faith was indeed a doctrinal rule: any difficult or delicate passage was aligned with the generality of doctrine defined elsewhere. 
not those who had the gift of foretelling things to come, but those who had a particular gift not only of expounding (modo interpretandae) Scripture, but also that of accommodating it wisely and applying it according to the people and the time." 25

Calvin did not invent this restriction of contemporary prophecy to the interpretation of the Bible. The close connection between prophecy and exegesis was in fact stressed in the name adopted by the Zurich school of exegesis-die Prophezei-referring to another passage from Paul: "Let the prophets speak two or three, and let the others judge." 26 In translating 1 Corinthians 14, Zwingli rejected Luther's translation of "propheteuein" by "weissagen" (divine, foretell), and adopted the transliteration "propheten," the corresponding noun being "Prophecy." Commenting on the first occurrence of the word in Paul's chapter, the Zurich reformer noted, "[Prophecy] ist usslegung der gschrifft" [(Prophecy) is explanation of the Scripture.]. ${ }^{27}$ And since June 1526, at eight o'clock every weekday morning except on market day, Friday, the pastors, preachers, and students of Zurich have gathered in the Grossmünster for the Prophezei, the reading, translation, and commentary of the Bible.

Calvin may have learned of this practice and this title during his stay in Strasbourg, all the more since the same name was current in the Alsatian city; but he need only to have read Erasmus's annotation (from 1516) on 1 Cor. 14:1: "Hoc loco Paulus prophetiam vocat, non praedictionem futurorum, sed interpretationem divinae scripturae (Paul here calls prophecy not the foretelling of future events but the interpretation of Holy Scripture)." 28

In his own commentary on this verse, Calvin adopted almost verbatim the Erasmian formulation: "prophecy is not the gift of foretelling future events." 29 This meaning of prophecy and its associa-

25. Commentarius in epistolam priorem ad Corinthios (12:28) (CO 49, col. 506); Commentaires sur toutes les Epistres, 1:292.

26. The reference is to 1 Cor. 14:29. Cf. Gottfried Locher, Die Zwinglische Reformation im Rahmen der europäischen Kirchengeschichte (Göttingen: Vandenhoeck und Ruprecht, 1979), 161-63; Bernard Roussel, "Des auteurs," ch. 6 in Le Temps des réformes et la Bible, ed. Guy Bedouelle and Bernard Roussel, Bible de tous les temps 5 (Paris: Beauchesne, 1989), 219 f.; Traudel Himmighöfer, "Die Prophezie," ch. 8 in Die Zürcher Bibel bis zum Tod Zwinglis (1531): Darstellung und Bibliographie, Veröffentlichungen des Instituts für europäische Geschichte Mainz im Auftrag der Abteilung Religionsgeschichte 154 (Mainz: von Zabern, 1995), 213-35.

27. Himmighöfer, Die Zürcher Bibel, 180-84.

28. Novum instrumentum (1516; reprint, Stuttgart-Bad Cannstatt: Fromann Holzboog, 1986), 477. Himmighöfer made the connection earlier, in Die Zürcher Bibel, $181 \mathrm{f}$. (quoting the Ratio seu methodus and the note on 1 Cor. 14:1).

29. In Latin, "prophetiam non esse vaticinandi donum." Cf. CO 49, col. 517; Commentaires sur toutes les Epistres, 1: 298. 
tion with Calvin was moreover so widespread in Geneva that Estienne Anastase wrote, in "The Printer to the Church of Jesus Christ," preface to Sermons de Jean Calvin sur les dix commandemens de la Loy (1559): "Among the excellent gifts with which God has enriched his Church at all times, one of the most useful and necessary is that of prophecy, which is knowing how to expound correctly and purely to the people of God the Holy Scripture according to the true and natural sense, and how to accommodate it appropriately to the present time and according to the people with whom one is dealing." Anastase had listened attentively to Calvin's sermons, so that he could reconstitute so faithfully the spirit and the words of the preacher, and so that he could regard him also as a prophet.

For Calvin had regularly alluded to his prophetic mission, more or less explicitly. In a sermon on Daniel 5 in 1552, he had claimed, "For if one preaches in this city that God's vengeance will be felt, that people do not wish to receive what we announce in the name of God, and that it is in his name that we have spoken, that there has been a prophet, they will ridicule all that." 30

Calvin clearly associated his preaching with a prophetic act. He did not, however, overlook the criticism of those who immediately reproached him for this legitimation. Indeed, a few weeks later, he replied, again from the pulpit, through the medium of a sermon on the book of Ezekiel. "There are some today who say: 'There's Calvin who makes himself a prophet, when he says that one will know that there is a prophet among us. He's talking about himself.' Is he a prophet? Well, since it is the doctrine of God that I am announcing, I have to use this language." ${ }^{31}$ The implication could hardly be clearer. Some ten years later, preaching on a New Testament text this time, on the passage in which Simeon is warned by the Holy Spirit, Calvin made a similar affirmation: "But when we compare ourselves with him, we certainly have more cause to be satisfied than he had. The Holy Spirit has not appeared to us, he has given us no special revelation, true, but Jesus Christ has brought us all the fullness of grace, so that we may as it were draw from him as the fountain everything to satisfy us.... So when we have all these things, what ungratefulness it is on our part if we still complain, and that it hurts us that we are not prophets?"32

30. Cf. CO 41, col. 335. The italics are of course mine.

31. The fifth sermon on Ezekiel is quoted by Stauffer, "Les Discours à la première personne," 196 and $n .45$, for the reference and the parallel passage; the quotation is repeated by Cottret, Jean Calvin, 205. But the reference to the twenty-first sermon on Daniel is incorrect.

32. The thirtieth sermon on the Harmonie évangélique, on Luke 2:26 (CO 46, col. 370; sermon preached in 1559 or 1560 ). 
It would be possible to multiply the references to the prophetic function that Calvin claimed discreetly, without perceiving the consequences that follow from this attribution for his interpretation of the Bible; we must therefore examine this interpretation further. Before doing so, one last astonishing passage demands our attention. It appeared on 9 February 1560, during a sermon on Genesis that referred to a text from the prophet Joel. This verse ("your sons and your daughters shall prophesy") seemed to contradict the restriction on the gift of prophecy, since it applied generally to all the children of the chosen people. In the pulpit, and unlike what he says in his commentary, Calvin accepted this generalization:

We also shall have the title of prophet, when we are true pupils of God. It is true that we shall not all have the role of doctors, but nonetheless Joel, ${ }^{33}$ speaking of the knowledge which will be given by the Gospel on the coming of the redeemer, says that all will be prophets, indeed both men and women, both young and old. So, when we have profited in the school of our God, to rely on him and have our recourse to him, he will do us this honor of treating us as his prophets. Although we are like the scum of the earth, though people despise us and spit in our faces, and though these grandees who are especially in royal courts today look on us as less than nothing, nevertheless God will take care of us. ${ }^{34}$

Calvin had indeed adopted the generalization, but his interpretation slid from the role of prophet to that of pupil of God--an expression that the reformer valued highly and used frequently in his homiletic expositions. ${ }^{35}$ The prophet thus became the person who knew Chris-

33. Joel 2:28: "And it shall come to pass afterward, that I will pour out my Spirit upon all flesh; and your sons and your daughters shall prophesy, your old men shall dream dreams, your young men shall see visions." In his commentary, Calvin referred this prophecy "to the reign and coming of Jesus Christ." He also played down the general import of the prophecy: "he Uoel] therefore does not affirm precisely that all will participate in this gift, but in relation to the ancient Church that this grace will be as it were common, as is fairly obvious" (Calvin, Petis Prophètes: Joel, 37; CO 42, col. 567). It is thus surprising that Calvin generalized the prophet's statement and applied it to the present time. If it was true that the danger of enthusiasm was less marked in Geneva than it was in Zurich or Strasbourg, this reference was rare in the discourse of the reformer. On the contrary, Calvin distrusted those who constantly had the word "spirit" in their mouth, and he denounced their audacity. See, for example, Responsio ad Sadolet $i$ epistolam, CO 5, col. 393; Contre la secte phantastique et furieuse des libertins qui se nomment spirituelz, CO 7, col. 176; Commentarius in epistolam priorem ad Corinthios, CO 49, col. 506.

34. The fifty-eighth sermon on Genesis (Gen. 12:16-20: Abraham has lied to Pharaoh about Sarah, passing her off as his sister, and the Lord punishes Pharaoh by crushing his armies), MS Bodl. 740, Bodleian Library, Oxford, fol. 403r.

35. The same expression is found in the lesson on Ezek. 2:8: "None is called to the office of minister or teacher, except insofar as he has profited in the school of God. This is why those who wish to be considered true pastors must have been pupils of God" (Leçons de $M$ Jean Calvin sur le prophète Ezechiel [Geneva, 1565], fol. 21v). 
tian doctrine and relied on God to conduct his life-in brief, a simple synonym for "Christian." Joel's generalization can thus be accepted, or rather set aside.

After this detour, we can now return to Calvin the prophet in the sense of "pure expounder" of Scripture, one who knew how to bring out "the true and natural sense" - the "natural sense" of a passage was also a favorite expression-in order to explore the consequences of this prophetic awareness.

In his sermons commenting on Scripture, Calvin regularly affirmed without any ambiguity that his message was true, inspired by God, and that all those who disagreed with him were wrong. Thus in 1560, in a sermon on Genesis, the congregation could hear, "And what is preached to us should not be taken as coming from a mortal creature, but we must always look higher, and receive with reverence what we know comes from there, that is from God." 36

Likewise, those who understood Scripture in a manner different from Calvin were in error. Commenting on Col. 2:14 ("blotting out the handwriting of ordinances that was against us") Calvin affirmed, "Commentators interpret this passage in different ways, but none of them satisfies me." ${ }^{37}$ He concluded his explanation by criticizing Erasmus, who "overturned the text," and by advising, "Remember the lesson which I have given as the true and natural one." 38

Somewhat impertinently, it is amusing to note a passage in a 1558 sermon on Isaiah in which Calvin quoted this same text from Colossians: "And in the other place ${ }^{39}$ he says in particular that the cross, although previously it had been a gibbet full of shame, was like a triumphant chariot, and that Jesus Christ had not only conquered the devil there, but he showed that we can now glory that we are absolved from all condemnation, that sin no longer has any power over us, and

36. The twenty-third sermon on Gen. 4:8-10 (MS Bodl. 740, fol. 134 r). Already in his "Reply to Sadoleto," Calvin wrote "that one must listen to the pastors of the Church as if to Christ himself, that is to those who truly carry out the office entrusted to them (audiendos ergo fatemur, non secus ac Christum ipsum, ecclesiasticos pastores, sed qui munus sibi injunctum exsequamur)" (CO 5, col. 404); Jean Calvin, CEuvres choisies, ed. Olivier Millet (Paris: Gallimard, Folio, 1995), 102. See also the first sermon on 1 Timothy, in September 1554: "if we wish to obey God, we must receive his word which is preached to us by those to whom he has entrusted this charge and office.... For the rest he [Paul] also shows that, if we wish to pay homage to God, if we wish to be his subjects, we must receive his word, when it is preached to us by the mouth of those whom he has sent" (CO 53 , col. 6); or the thirty-fifth sermon on the same epistle: "So do we wish to be governed by God? Let us know that we must take special care to choose ministers who are faithful and fit to exercise their office" (CO 53, col. 422).

37. Calvin, Commentaires sur toutes les Epistres, 593.

38. Calvin, Commentaires sur toutes les Epistres, 594.

39. Col. 2:14 f. 
that all the devils of hell are debarred from all that they could claim over us." 40

The Colossians text stated, in Calvin's translation, "[W]iping out the bondage which was laid on us in decrees, which was hostile to us, [he] has taken it from us, and fixed it to the cross; and has dispossessed the principalities and powers, and boldly led them on show, triumphing over them by [the cross]." In quoting this verse Calvin remembered his own commentary, in which he modified the apostle's formulation, rather than the original text. ${ }^{41}$ Indeed, it often happened, as I have shown elsewhere, ${ }^{42}$ that Calvin confused his interpretation with Scripture itself, when he quoted from memory a passage.

In my view, this freedom of quotation corresponds to that of an apostle or a prophet modifying Scripture in the act of quoting it, not respecting verbal fidelity. The relative liberty of Old Testament prophets when they quoted the Law is known; likewise, the apostles did not always quote the Old Testament faithfully. The Evangelists and St. Paul were among such innovative practitioners, departing from the text they were citing. In Matt. 2:6 (on the importance of Bethlehem), a very free quotation of Micah $5,{ }^{43}$ Calvin recognized the discrepancy, but minimized it: "Now there is something which should always be noted, that each time the Apostles quote some proof from the Scripture, although they do not give it word for word, although sometimes they depart considerably from it, nonetheless the passage is always properly and appropriately quoted." 44 Calvin did not condemn the discrepancy between source text and quotation text. On the contrary, he valorized the freedom with which the apostles departed from the

40. Sermon 261 on Isaiah (Isa. 52:13-53:1), dated 18 June 1558, MS London Huguenot Church, fol. 462v; see also CO 35, col. 602 .

41. Indeed, in the commentary we find: "Triumphing over them in it. It is true that the Greek text could be read: 'in himself,' but the context of the passage entirely requires that we read it as we have said; for what would be coldly said of Christ can be very aptly applied to the cross. For just as, earlier, he had compared the cross to magnificent spoils, or a noble instrument of triumph by which Christ led his enemies, now also he compares it to a triumphant chariot, in which he shows himself in great splendor. For, although there was only a curse in the cross, nonetheless it was so swallowed up in the power and strength of the son of God that it had in a sense put on a new nature, for there is no judicial seat as magnificent, there is no royal throne as excellent, there is no instrument of triumph as noble, there is no chariot as outstanding, as is this gibbet, on which Christ subjugated death and the devil, the prince of death, and altogether shattered them under his feet" (Calvin, Commentaires sur toutes les Epistres, 594).

42. See my article, "Calvin connaissait-il la Bible? Les Citations de l'Écriture dans ses sermons sur la Genèse," Bulletin de la Société d'Histoire du protestantisme français 141 (1995): 163-84.

43. Matt. 2:6 combines Mic. 5:6 and 2 Sam. 5:2.

44. Commentaires de Jean Calvin sur la Concordance ou Harmonie, composée des trois Evangelistes ... item ... sur le second livre de sainct Luc, dit les Actes des Apostres, Michel Blanchier, Geneva, 1563 (original ed. in 1555), in-fol., 52. 
Old Testament text. This was a long way from Erasmus who, on this same text from Matthew, renewed Jerome's criticism, which denounced biblical authors for trusting too much to their memory instead of rereading Scripture. ${ }^{45}$

Similarly, in Matt. 27:9, which names Jeremiah although the text comes mainly from Zechariah, Calvin returned to what he called a rule of the apostles: "I admit I do not know how the name of Jeremiah appears here, and it does not worry me much. Clearly the text shows that there is an error in putting the name of Jeremiah instead of Zechariah, for in Jeremiah this statement does not appear, nor anything like it. As regards the other passage, namely that from Zechariah, if one does not know how to accommodate it properly it could seem to be quoted inappropriately. But if we remember the rule which the Apostles followed in quoting Scripture, we shall easily recognize that what is said here applies excellently to Christ." 46 Once again, Calvin played down the confusion between the prophets' names; but above all he appealed to the apostles' rule, that is to say, the liberty that they exercised in quoting a given biblical passage, since even if the expression was not found as such, they were inspired by the Holy Spirit.

Calvin picked up the discrepancies and explained them. He did not, however, attribute any importance to them, since he absorbed them into an apostolic rule. It is thus scarcely surprising that in the Harmony and the commentary on Acts, the differences between the two accounts of the death of Judas (Matt. 27:9 ff. and Acts 1:16-19) were not even mentioned. ${ }^{47}$

The apostles could distance themselves from the literal in their quotations from the Old Testament, both in form and in the circumstances of the quotation, thus perpetuating the practice of the prophets in relation to the Law. Calvin had this same relationship with the biblical text, so close to the Spirit that he dared distance himself from the Letter ${ }^{48}$ Like the prophets, Calvin did not introduce a new doc-

45. Quoted by André Godin, Erasme lecteur d'Origène, Travaux d'Humanisme et Renaissance 190 (Geneva: Librairie Droz, 1982), 171.

46. Godin, Erasme, 504.

47. Godin, Erasme, $504 \mathrm{f}$., and second part (Acts), 20. But Calvin did recognize that the text on the death of Judas was an interpolation.

48. In the preface to his commentary on Isaiah, Calvin gave his clearest explanation of Old Testament prophecy (Commentaires sur le Prophète Isaï [Geneva: Adam and Jean Riveriz, 1552], fols. 6r-8v; Joannis Calvini commentarii in Isaiam Prophetam, in CO 36, cols. 19-24), a point clearly noted and analyzed by Olivier Millet, La Dynamique de la parole, 268-71. To give simply one significant extract from this preface, developing the triple task of the prophets: "The prophets therefore explain more at length and more fully the doctrine which is briefly contained in the two tables [of the Law], and teach what is principally required by the Lord. As regards the threats and promises which Moses indicated in general, they apply them to their own time, and give them specific relevance. Finally, 
trine,$^{49}$ but the discrepancies he allowed himself always backed up his assertions. One may also note that Calvin did the same in relation to classical writers and the church fathers, ${ }^{50}$ a technique far from unique in his age as in ours. Montaigne would do the same, borrowing from numerous sources, "disguising and deforming [his borrowings] to a new end," as he asserted without shame, ${ }^{51}$ and even stating in the 1588

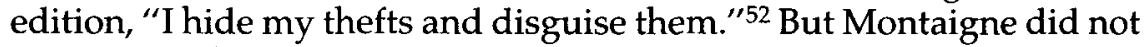
argue to be the true expounder of the Bible.

\section{CALVIN, ADMONISHER OF THE GOVERNMENT}

Calvin revealed his prophetic awareness not only as biblical commentator, but also in his role as admonisher of the government. Already in the "Epistle to the King," which introduced the Institutio religionis christianae in 1536, Calvin presented himself as advisor to the monarch, and as lawyer for the defense of the Reformed cause. This slightly offhand approach, ${ }^{53}$ setting aside all courtly pomp, was immediately followed by a distinctly unceremonious call to order. In replying to the attacks to which the evangelical movement in France was subject, Calvin harangued his sovereign:

It is your duty, Sire, to turn away neither your ears nor your heart from so just a defense, especially when the subject is so great, namely how the glory of God shall be maintained on earth, how his truth shall retain its honor and dignity, how the rule of Christ shall be

what is said somewhat obscurely in Moses concerning Christ and his grace, they declare more openly, giving fuller and more abundant evidence" (fol. 6r; CO 36, col. 19).

49. What Calvin says of the prophets- "Thus when the prophets talk about behavior, they bring in nothing new [nihil novi], but declare things which were poorly understood in the Law" (Commentaires sur le Prophète Isaïe, fol. $7 \mathrm{r}$; in Isaiam, col. 21) —can also be said of Calvin in relation to doctrines: he never introduced a new one.

50. Pliny, Histoire Naturelle, ed. E. de Saint-Denis (Paris: Belles-Lettres, 1961), 10.59 (page 48); in taking over the example of the crane that holds a pebble to prevent it from going to sleep, Calvin displaced the pebble from the feet to the beak of the bird, which makes the exercise more ascetic; see sermon 5 on Genesis, MS Lambeth Palace, London, fol. 25r. See also Irena Backus, "Calvin's Judgment of Eusebius of Caesarea: An Analysis," Sixteenth Century Journal 22 (1991): 419-37; here with the example of Eusebius of Caesarea, Backus's study shows that these discrepancies do not stem only from a deficient memory, but from an intention to achieve proof. An earlier version of her article appeared in Calvinus Sacrae Scripturae Professor, ed. W. H. Neuser (Grand Rapids, Mich.: Eerdmans, 1994), 233-36.

51. Montaigne, Essais, 2d ed. (Paris: Villey-Saulnier, 1992), 3.12 (page 1056). Passage quoted by Michel Jeanneret in Perpetuum mobile: Métamorphoses des corps et des auvres de Vinci à Montaigne (Paris: Macula, 1997), 267.

52. Montaigne, Essais, 3.12.

53. See the subtle analysis of the epistle "Au Roy de France" in Olivier Millet, La Dynamique de la parole, 464-77; the surprising absence of a grandiose preamble is stressed (469). See also Jean-François Gilmont, Jean Calvin et le livre imprimé, Cahiers d'Humanisme et Renaissance 50 (Geneva: Librairie Droz, 1997), $269 \mathrm{f}$. 
maintained in its entirety. A subject indeed worthy of your ears, worthy of your justice, worthy of your royal throne. For this is the consideration which makes a true king, if he recognizes himself as the true servant of God in the government of his kingdom. And on the contrary, he who does not rule with the aim of serving the glory of God does not practice rule but robbery. Thus it is an error to expect long prosperity in a reign which is not governed by the scepter of God, that is to say by his holy Word..$^{54}$

The harangue was determined, bordering on insolence, joining a warning and a scarcely veiled condemnation: if you do not defend our cause, the true cause of God, you are not a king but a robber. One recognizes the boldness of which the prophets were capable in the biblical narratives of Isaiah, Hosea, or Jeremiah: "Say unto the king and to the queen-mother, Humble yourselves, sit down: for your headtires are come down, even the crown of your glory" (Jer. 13:18). In his epistle, as we have just heard, Calvin reminded the king that an earthly kingdom must be governed by the Holy Scripture, the scepter of God. But how, precisely, was this word of God to be understood? Calvin replied by giving his monarch a lesson in exegesis. "When Saint Paul wished that all prophecy should be according to the analogy and proportion of faith [and we recognize the quotation from Rom. 12:1 seen above], he gave a most reliable rule for testing all interpretation of Scripture. Now, if our doctrine is examined by this rule of faith, the victory is in our grasp." 55 The demonstration was unrelenting, and one wonders how Francis I did not succumb. Did he ever read it? There are good reasons to doubt if he did. In any case, as from 1536 Calvin adopted a prophetic stance in relation to his sovereign, making clear his authority to interpret Scripture according to divine truth.

It will also be remembered that Calvin's first printed text as a Protestant, in 1535, was a pseudo-privilege for the Olivétan Bible, in which the young humanist addressed himself to "emperors, kings, princes and to all peoples subject to the sovereignty of Christ," demonstrating his spiritual authority.

Likewise, several of his works are dedicated to monarchs, and it is perhaps in the dedication of the first version of his commentary on Isaiah, dated 25 December 1551, that Calvin compared most explicitly the ministry of the Old Testament prophets with his own prophetic

54. John Calvin, "Epistre au Roy," in Institution de la religion chrestienne, ed. J.-D. Benoît (Paris: Vrin, 1957), 30.

55. Calvin, "Epistre au Roy," 31.

56. See the French translation and the Latin text edited by Bernard Roussel, in Le Livre et la Réforme, ed. Rodolphe Peter and Bernard Roussel (Bordeaux: Revue française d'Histoire du livre, 1987), 243-61. 
ministry. The book is dedicated to King Edward VI of England. Calvin spoke very subtly to the young monarch, just as, he stressed, Isaiah did long ago to various kings. ${ }^{57}$ For God "has begun to set up again what was fallen ... and he has chosen as his architects modest persons from among the common people to advance this work by the pure doctrine." These men may be of lowly birth, but with what bravado they address the high and mighty:

And here I admonish you personally, most excellent King, or rather God appeals to you by the mouth of Isaiah, that you persevere in using all the force and power you have to advance more and more the restoration of the Church, which is proceeding apace in your kingdom. Firstly you hear and read daily that this charge is laid upon you in the kingdom over which you rule. And likewise Isaiah ... does not permit that the aid which [the Church] demands from you in its affliction should be lacking. Also, your heart should be moved not a little by the fact that the prophet pronounces a curse on all kings and people who deprive it of their aid.... And most noble King, it is very necessary that you be ready and alert in relation to the charge which is committed to you, seeing that Isaiah exhorts all kings and magistrates, in the person of Cyrus, to stretch out a hand to the suffering Church, that it may be restored to its rightful condition..$^{58}$

The biblical text and Calvin's text are carefully blended together, not to weaken the rigor of the admonition, but to place it constantly under the authority of the biblical writer, perfectly interpreted by the modern prophet.

However, the various addressees of Calvin's admonitions did not all accept them with the same willingness as Edward VI. The difficulties encountered by Calvin in Geneva itself between 1545 and 1555 with the members of the Perrinist party, the Genevan "libertines," are well enough known to need no more than a simple reminder.

Apart from these vigorous, but polite, admonitions, Calvin regularly spoke in extremely violent terms of the succession of French kings who followed Francis I, describing them as "earthworms," "frogs," "fleas," "excrement," "old boots," spitting in their faces, and judging their edicts and orders as "filth and excrement" in various sermons preached between 1550 and 1562..$^{9}$ The Petrine principle (Acts 5:29) entirely dominated Calvin's political thought in relation to religious questions: one must obey God rather than men. When the

57. Letter 1422 (CO 13, cols. 669-74); Commentaires sur le Prophète Isaïe.

58. Commentaires sur le Prophète Isaïe, fol. $4 \mathrm{r}-5 \mathrm{r}$.

59. See my "Calvin monarchomaque? Du soupçon à l'argument," forthcoming in Archiv für Reformationsgeschichte. 
prince was an idolatrous tyrant, Calvin found prophetic tones in which to denounce him.

The Petrine principle was not exclusive to Calvin; he shared it with his friends. Thus we find in Viret, "Those who are true servants of God and are legitimately called to the ministry of his Church ... are not bound to do what is proper for princes or for magistrates; so, on the other hand, if they do not speak out and do not address themselves to princes and governors in all freedom, as is their office, they would be deeply guilty, for they would be numbered with the dumb dogs of which Isaiah speaks. For their office demands that they require princes and governors, according to God's law, to do their duty. ... To whom then does it more belong to offer this book than to the true prophets of God?" 60 In Viret also the admonition of the sovereign was justified and founded in a basic prophetic gesture. After the death of Calvin, moreover, the Genevan pastors continued to recognize in the Old Testament prophets the model for their admonition of the magistrates. ${ }^{61}$

\section{Calvin's Prophetic Self-Awareness}

Calvin was acutely aware of his prophetic vocation. Several forceful assertions, a number of verbal audacities, and many thoughtful remarks suffice to characterize eloquently the awareness that Calvin had throughout his life of his prophetic vocation, of his consciousness of being powerfully inspired by the Holy Spirit. The prophet's voice, finding its breath in God's inspiration, was so strong that it needed no development. Calvin constantly recognized it. Commenting on the astonishing passage from Ezekiel, "open thy mouth, and eat that I give thee" (Ezek. 2:8), which immediately turns into a book that the prophet ingests (v. 9), the reformer explained that "it is just as if God made a mortal man the instrument of his Spirit." ${ }^{62}$ Likewise, Calvin was conscious of being a mortal man, instrument of God by the power of the Holy Spirit. Without repeating what others have written on this subject, I would simply like to add a final stone to the edifice, a tombstone.

60. Pierre Viret, Remonstrances aus fideles qui conversent entre les papistes, et principalement à ceus qui sont en cour et qui ont offices publiques, touchant les moiens qu'ils doivent tenir en leur vocation à l'exemple des anciens serviteurs de Dieu (1547; Geneva: Jean Rivery, 1559), $28 \mathrm{f}$.

61. For example, Eugène Choisy, L'État chrétien calviniste à Genève au temps de Théodore de Bèze (Geneva: Eggimann, 1902), 470-3, and the references given in 470 n. 1.

62. See Leçons de M. Jean Calvin sur le prophète Ezechiel, fol. $22 \mathrm{v}$. The same idea was developed in the lesson on Jer. 15:16 (Jeremiah eating the words of God), Jeremiah and Ezekiel having both attended "the school of the Holy Spirit" (Leçons ou commentaires et expositions de Jean Calvin, tant sur les Revelations que sur les Lamentations du Prophète Jeremie [Lyon: Claude Senneton, 1565], 356). 
Rare indeed are the books annotated in Calvin's hand that have survived. One of these is an edition of the works of John Chrysostom. The reformer read the seventy-seven sermons on Genesis, certainly during the first years of his ministry in Geneva, underlining and adding a few words in the margins of his copy. ${ }^{63}$ In the penultimate sermon, on the burial of Jacob, he wrote in the margin, "De sumptuosis sepulturis" [About sumptuous graves], and above all he underlined the passage, "prophetas dico et apostolos, ubi sint, paucis exceptis, ignoramus" [I say about prophets and apostles, where they have been buried, except a few of them, we do not know it.] ${ }^{64}$ Indeed, in Deut. 34:5-6, we find, "So Moses the servant of the Lord died there in the land of Moab, according to the word of the Lord. And he buried him in the valley in the land of Moab, over against Beth-peor: but no man knoweth of his sepulchre unto this day." In his commentary, Calvin insisted on God's personal engagement in himself burying Moses (which eliminated any "trick"), and added, "Now although the reason for hiding it is not stated, nevertheless it seems clear that God's intention was to prevent any superstition which could arise. . . He thus took steps early, so that the people by the thoughtless impetuosity of their zeal would not overturn the decree of God." 65 In his commentary on verse 9 of the Epistle of Jude (the devil and the archangel Michael arguing over the body of Moses), Calvin had already given an identical interpretation, in order that the body of Moses should not become "an object of superstition," 66 and the same reflection began and ended his Traité des reliques (Treatise of relics). ${ }^{67}$

63. Divi Joannis Chrysostomi archiepiscopi Constantinopolitani opera (Paris: Claude Chevallon, 1536), 1: fol. 1r-135r. These notes have recently been published by Alexandre Ganoczy and Klaus Müller, Calvins handschriftliche Annotationen zu Chrysostomus: Ein Beitrag zur Hermeneutik Calvins, Veröffentlichungen des Instituts für europäische Geschichte 102, (Mainz: Steiner, 1981).

64. "Je dis que nous ignorons le lieu où furent enterrés les prophètes et les apôtres, à l'exception de quelques-uns" (Divi Joannis Chrysostomi, 1: fol. 131v).

65. Commentaires de M. Jean Calvin sur les cinq livres de Moyse (Geneva: François Estienne, 1564), $714 \mathrm{f}$. (second pagination). Note that Celsus also quotes this text from Deuteronomy (Origen, Contre Celse, 2.54).

66. Ignorance of the place where Moses was buried becomes the central argument in favor of the authenticity of the epistle: "Now no one was ignorant why his tomb was hidden, that is, so that the Jews should not offer his body as an object of superstition. So should we be astonished that Satan has tried to show the body of this saint which God had hidden? But the angels resisted, as they are always ready to do service to God. And in fact, we see that in all ages Satan has tried to turn the bodies of faithful servants of God into idols for the poor ignorant and ill-advised; so because of this witness we should not view this epistle with suspicion, although this witness is not found in scripture" (Commentaires de M. Jehan Calvin sur les Epistres canoniques de s. Pierre, s. Jehan, s. Jaques et s. Jude, lesquelles sont aussi appelées catholiques [Geneva: Conrad Badius, 1556], 164).

67. John Calvin, Three French Treatises, ed. Francis Higman (Oxford: Oxford University Press, 1967); and Calvin, CEuvres choisies, 190, 247. 
Today, in the Plainpalais cemetery, which is now in Geneva intra muros, no tomb can be found containing the remains of Calvin. The reformer demanded explicitly to be buried anonymously, because he was aware very early that his body could become an object of worship, and he wished that his tomb should be in no way different from that of others, stating in his will that he wished to be "buried in the accustomed fashion." 68 The authorities obeyed his wish so precisely that a few months after his burial, as Nicolas Colladon relates in 1565, "certain students who had come here recently to study found themselves deceived one day when they went to the cemetery specifically to see Calvin's tomb, for they thought they would see some grand, towering monument, and there was nothing apart from simply earth, like the others." 69 Calvin had been buried in the manner of an Old Testament prophet, ${ }^{70}$ as he had long hoped.

This prophetic awareness illustrates the special vocation that Calvin knew was his. It is now easier to understand a passage from the confession of faith of the French churches (1559), known as the Confession de La Rochelle, in the thirty-first article: "We believe that none may involve himself on his own authority in the government of the Church, but that this must be done by election (Matt. 28:19; John 15:16; Acts 1:21, 6:1-3; Rom. 10:15; Titus 1:5), insofar as this is possible and as God allows it; we make this exception particularly because it has sometimes been necessary, indeed in our own time, when the state of the Church had been interrupted, that God raise up people in an extraordinary manner to set up anew the Church which was ruined and desolate. Nonetheless, we believe that one must always conform to this rule, that all pastors, elders and deacons have a witness that they are called to their office (Gal. 1:15; 2 Tim. 3:7-10, 15). ${ }^{71}$ The pastors and leaders of Reformed communities must first have received a calling ("have a witness that they are called to their office"), then, in a second movement, be elected ("this must be done by election"), which implied a training process. Some, however, were directly raised up by God "in an extraordinary manner," because the church was in a time of crisis. Calvin, who never took a course in theology and was never ordained as a pastor, was directly raised up by God in an extraordinary manner to be the prophet of the church of Geneva, its leader, and

68. "Testament de Calvin," in "Thesaurus epistolicus Calvinianus," no. 4103, CO 20, col. 300.

69. "Vie de Calvin," revised and augmented by Nicolas Colladon, in CO 21, col. 106.

70. Certain ancient sages were no more concerned about their tombs, or even about being buried, as Cicero says about Diogenes (cf. Tusculanes, 1.43.104). Calvin's gesture did not, however, stem from this sagacity.

71. Confessions et catéchismes de la foi réformée, ed. Olivier Fatio et al. (Geneva: Labor et Fides, 1986), 125. 
its faithful and authorized expositor of holy Scripture. This was recognized even in the confession of faith of the Reformed Church.

\section{CONCLUSION}

In 1555, Nostradamus put out a quatrain attacking the preaching on the banks of Lake Geneva that seems to me more aimed at Geneva and Calvin than at Lausanne, Viret, and Beza, or Thonon and Fabri:

From Lake Leman the sermons will annoy:

Days will be reduced by weeks,

Then months, then years, then all will fail:

The magistrates will curse their empty laws. ${ }^{72}$

Though less abstruse than others, this quatrain is sufficiently obscure to justify Montaigne's ridicule of the "prophetic jargon to which their authors give no clear sense, so that posterity can make it mean anything they want." ${ }^{\prime 3}$

Michel de Nostradamus's prophecies were much appreciated in the Renaissance, which liked popular almanacs and shepherds' calendars, Daniel's Dreams and various prognostications. Calvin did not reply to Nostradamus in these terms, since his gift of prophecy was different, rejecting any judicial astrology. And if Beza once was carried away enough to call Calvin a seer, I find no further trace of the idea in the prefaces to the various works of Calvin published by Beza. ${ }^{74}$ Only a few months after the reformer's death, Beza, carried away by his boundless admiration, had been happy to turn a general proposition (there were still battles to come) into an actualized prediction, since the first war of religion had occurred.

I have tried to define not whether Calvin was a prophet, but according to what modes. In the acute consciousness that he had of his

72. Les premières Centuries ou propheties (edition by Macé Bonhomme, 1555), with commentary on the "Epître à César" and the first 353 quatrains by Pierre Brind'amour, Textes littéraires français 468 (Geneva: Librairie Droz, 1996), q. 47, 117. A quatrain from the second century also prophesied a famine in Geneva (Les premières Centuries, q. 164, 286).

73. Montaigne, Essais, "Des prognostications," 1.11.44. Montaigne also said (in 1.30.208A, "Des cannibales"), that "divination is a gift of God."

74. I have consulted the preface of the Recueil des opuscules: C'est à dire Petits traictez de M. Jean Calvin (Geneva: Baptiste Pinereul, 1566), dedicated to Renée de France; even if in these pages Beza defended Calvin's forcefulness, there was no reference to prophecy (Correspondance de Théodore de Bèze, Travaux d'Humanisme et Renaissance 136 [Geneva: Librairie Droz, 1973], 7: 97-103 [no. 468]); the dedicatory epistle to Frederick III, Elector Palatine, for the Epistolae et responsa of 1575 (Correspondance de Théodore de Bèze, ed. Alain Dufour, Béatrice Nicollier and Reinhard Bodenmann, Travaux d'Humanisme et Renaissance 273 [Geneva: Librairie Droz, 1993], 16:18-20 [no. 1116]); or, from the following year, the preface to Tractatus theologici omnes dedicated to William of Orange (Correspondance de Théodore de Bèze, Travaux d'Humanisme et Renaissance 286 [Geneva: Librairie Droz, 1994], 17: 74-85 [no. 1193]). 
calling as a reformer of the church, in his very special relationship with Scripture, helped by what he called the inner witness of the Holy Spirit, in his role as defender of the Reformed cause in the face of government, right up to his tomb, Calvin conducted himself like an Old Testament prophet. If his fellow believers particularly recognized this calling and the prophetic value of his interpretation of the Bible, Calvin was not alone in believing himself to be in the succession of the prophets. John Knox identified himself, explicitly as well as implicitly, with the prophet Ezekiel, ${ }^{75}$ and Zwingli, earlier, also considered himself as a prophet. ${ }^{76}$

In his latest book, Michel Jeanneret recalls that, in the Renaissance, the myth of the intellectual hero was put forward forcefully, writers and artists posing as predestined individuals. ${ }^{77}$ To this construct can be added the conviction held by certain reformers that they were modern prophets sent by God, having received an individual calling to restore the relation between God and men. Of course they reaffirmed the infinite distance separating the Creator and his creatures, between the goodness of God and the sin of men, but in order to do so they spoke as if they were very close to God, so close that they called themselves his mouth, like prophets of the Old Testament.

75. Cf. W. I. P. Hazlett, "'Jihad' against Female Infidele and Satan: John Knox's First Blast of the Trumpet," in Calvin: Erbe und Auftrag: Festschrift für Wilhelm Neuser, ed. W. Van't Spijker (Kampen: Kok Pharos, 1991), 285; see also Peter Auksi, "'God shall alwayes raise up some': John Knox, the Reformer as Prophet" (paper presented at "The Laws and Prophets in the Middle Ages and the Renaissance," University of Western Ontario, April 1997).

76. Himmighöfer, Die Zürcher Bibel, 184; Fritz Büsser, “Der Prophet: Gedanken zu Zwinglis Theologie," in Würzeln der Reformation in Zürich: Zum 500. Geburtstag des Reformators Huldrych Zwingli (Leiden: Brill, 1985), 49-59.

77. Jeanneret, Perpetuum mobile, $240 \mathrm{f}$. 